\title{
THE LAUNCHING OF THE STUDENT SIT-IN MOVEMENT: THE ROLE OF BLACK WOMEN AT BENNETT COLLEGE
}

\author{
Deidre B. Flowers*
}

This essay explores the involvement of the women of Bennett College in the student-led sit-in movement that was launched in Greensboro, North Carolina in February 1960. On 24 February 2003, Dr. Johnetta B. Cole at a book talk at the Schomburg Center for Research in Black Culture with coauthor Dr. Beverly Guy-Sheftall of Gender Talk: The Struggle for Women's Equality in African American Communities, mentioned that there has been very little research on the women of Bennett College who participated in the student-led sit-ins in the early $1960 \mathrm{~s} .{ }^{\mathrm{I}}$ This essay will examine the student participants in the movement and the theories of organization that help to provide explanations for these protest activities. Within the context of the Supreme Court's 1954 Brown v. Board of Education decision, background information on the city of Greensboro, North Carolina, will be presented. In addition, the significance and impact of historically black colleges and universities (HBCUs) in general and the student-led sit-ins in particular on the evolving social consciousness in the African American community will be assessed. ${ }^{2}$

When the United States Supreme Court made its unanimous ruling in the Brown v. Board of Education case on 17 May 1954, legal segregation in public education became unconstitutional, overturning the "separate but equal" doctrine of the 1896 Plessy v. Ferguson decision. ${ }^{3}$ Civil Rights attorney Constance Baker Motley in Equal Justice Under the Law: An Autobiography, declared that the Brown decision "ushered in the greatest period of social upheaval since the Civil War" as the hopes and expectations of thousands of southern African Americans in particular were raised. ${ }^{4}$ Expectations centered on the elimination of all Jim Crow practices because many believed that this would allow African Americans to enjoy the full rights and privileges of their U.S. citizenship. The launching of the Greensboro student-led sit-ins in 1960 represented a new phase in the social upheavals associated with the Civil Rights Movement.

\footnotetext{
*Deidre B. Flowers is a Financial Analyst at Columbia University and a masters degree student in the Higher and Postsecondary Education Administration Program at Teachers College, Columbia University in New York, NY.
} 


\section{GREENSBORO, NORTH CAROLINA}

On 1 February 1960, four male North Carolina Agricultural and Technical College (NCA\&T) students walked into the F. W. Woolworth's store in Greensboro, North Carolina, "purchased school supplies and sundry items," then proceeded to the lunch counter and took seats to wait for service. 5 The act of taking a seat at the lunch counter and requesting service represented an act of defiance aimed at the South's Jim Crow laws and practices that defined the nature of social interactions between whites and African Americans in the South. ${ }^{6}$ The city of Greensboro was established as the county seat of Guilford County in 1808, and was "a center of antislavery activity, a way station of the Underground Railroad, and a gathering place for Quakers."7 Also considered a city of the "New South," Greensboro was considered by some to be "free of old prejudices and ideally prepared to lead the region toward new levels of prosperity and enlightenment." 8 Therefore, given its reputation, there was the expectation among African Americans that following the Brown decision there would be little difficulty in the movement towards desegregating the schools and other public facilities. Unfortunately, it was not until 1971 that the Greensboro public school system was desegregated. ${ }^{9}$

By 1960 Greensboro was home to five colleges; two HBCUs and three traditionally white institutions (TWIs). ${ }^{10}$ The two HBCUs were Bennett College, a private college for women, and NCA\&T, a public, coeducational institution. Bennett College was founded under the auspices of the Methodist Church, initially for the purpose of educating male and female students. Bennett first accepted students for collegiate study in 1920, forty-seven years after its founding, and in 1926 began admitting only female students. Among the more than one hundred HBCUs, only four were dedicated solely to the education of African American women. Scotia College was founded 1867 in Concord, North Carolina; and Tillotson College was founded 1875 in Austin, Texas. Both colleges, in 1932 and 1935 respectively, merged with other institutions and became coeducational. Only Spelman College founded 1881 in Atlanta, Georgia, and Bennett College continued to provide higher education solely for African American women. The other three colleges in the city were Greensboro College founded in 1838 by the Methodists; Guilford College chartered in 1837 by the Society of Friends (Quakers); and Women's College founded in 1892, which was taken over by the University of North Carolina at Greensboro in 1931.11

\section{ORIGINS OF THE STUDENT SIT-INS}

In rendering the 1954 Brown decision and Brown II the following year, the Supreme Court provided no timetable for an end to public school segregation, only that it was to be implemented "with all deliberate speed." Historian Paula Giddings noted this lack of a "prescribed timetable" for implementation of school desegregation as the primary reason for the 
growing discontent within the African American community. ${ }^{12}$ It was in this socially and politically charged atmosphere that students became unwilling to continue to accept the status quo and chose to take a stand against discrimination and segregation. National and local figures in the Civil Rights Movement recognized the students' efforts. Thurgood Marshall, lead attorney for the NAACP's Legal Defense Fund, believed that students had chosen this form of protest because "young people are impatient with the slowness of court action in furthering equality." Marshall later praised students because they had "set their elders an example to follow and that adult Negroes should stop sitting on the sidelines 'wringing your hands."'13 Martin Luther King, Jr. noted that the student's efforts were the beginning of a move "away from tactics which are suitable merely for gradual and long term change-lengthy court battles and efforts to get action by Congress;" and that "the Negro students are saying, we will not wait for long litigation... [and] delaying tactics." 14

Historians offer differing interpretations on the origins of the 1960 student sit-in protests. Some suggest that the sit-ins were "spontaneous and self-sufficient," while others suggest they were "simple and impulsive" acts of defiance by the students who simply wanted "to drink a cup of coffee sitting down." 15 Other scholars have suggested that the sit-ins were the result of "rational planning, a well established leadership, effective communication networks, and economic support from blacks themselves." These were the reasons why the protests spread so quickly through the South. ${ }^{16}$ Whatever the origins, some things are clear about the student sit-ins: 1) they had as their main goal an insistence on dignity and respect, and full access to all public facilities available to American citizens; 2) they were primarily organized and executed by the students themselves; 3) they were supported by African Americans in the local communities where they occurred; 4) they took the leaders of the established civil rights organizations-NAACP, the Congress of Racial Equality (CORE), and the Southern Christian Leadership Conference (SCLC) - by surprise; and 5) they have been credited with inspiring and reinvigorating these established civil rights organizations. ${ }^{17}$

While there is agreement that the civil rights leadership was surprised by the student's organized efforts, scholars present differing views regarding the student leaders' connections to the established organizations. Some argued that the students were fully capable of organizing and executing the sit-in campaigns. For example, Robert Weisbrot and Howard Zinn make no mention of connections to other organizations in their discussion of the sitins; however, Aldon Morris and William Chafe have suggested that students were in communication and worked with other groups to plan and execute the protests. ${ }^{18}$ Several civil rights leaders as well as some college presidents also denied connections to outside organizations. College presidents and administrators frequently made the point that the students were acting on their own. Dr. Harold H. Hutson, president of Greensboro College, indicated that "students were acting as individual citizens" and "were not connected 
with the college"; while NCA\&T's Dean of Men W. H. Gamble indicated that "the college has no authority to restrict students' private activities of this kind."19 In some instances, college administrators planned no disciplinary action "unless the students were disorderly."20 Dr. George C. Simkins Jr., a local dentist and head of the Greensboro chapter of the NAACP, also claimed no prior knowledge of the February 1st demonstration. Despite this fact, he indicated that the local NAACP was "100 percent behind the idea and 'if any legal action arises as a result, the NAACP is prepared to back the group."'21

While the Greensboro lunch counter protests were concentrated between 1 February and 25 July 1960, these were not the first student-led sit-ins launched as part of the modern Civil Rights Movement. ${ }^{22}$ Bettye CollierThomas and V.P. Franklin chronicled major events of the Civil Rights Movement in My Soul is a Witness: A Chronology of the Civil Rights Era 1954-1965, and they documented student-led sit-ins that occurred in the late 1950 s in several states, including Oklahoma, Kansas, and Florida. ${ }^{23}$ Hugh Davis Graham similarly noted that between 1957 and 1960 nearly "sixteen southern towns experienced sit-ins," however, none of the sit-ins occurring prior to 1960 had "combined just the right mix of elements to spark social combustion." 24 Because of the rapid spread of the sit-in technique to other southern cities, Chafe and others have identified the Greensboro sit-ins as a watershed event in the emerging Civil Rights Movement that ignited a firestorm of racial protest that spread throughout the South. ${ }^{25}$ Chafe described how once the student sit-ins started, white political and economic leaders tried to "contain and diffuse" the protests. ${ }^{26}$ Tactics used to thwart the protests included arrest of participants, background investigations of Bennett and NCA\&T staff and students, and threats to cut off each institution's utilities, and in the case of NCA\&T, its funding.

The use of the sit-in technique was not new. Historian Benjamin Quarles traced the technique back to the Reconstruction era and concluded that what was new about the 1960 sit-ins was the "manner in which it captured the imagination of southern Negroes, especially college students," and its ability to stir the "conscience of the South and the nation." 27 Graham believed the sit-ins were "ideally scripted to set the tone of protest and activism for the $1960 \mathrm{~s}, "$ in that they were "black initiated and black led." 28 He argued that the values represented were "integrationist" though "conservative," and that they were an effective "mobilizing tool" because they created publicity and put pressure on establishments "with a substantial black trade."29 The effectiveness of the sit-ins as an "instrument of desegregation" lay in the fact that whites in power across the South were "hard-line segregationists," and they resisted desegregation efforts by vigorously enforcing Jim Crow laws. ${ }^{30}$ Despite their contagion and effectiveness, Constance Motley pointed out that the NAACP leaders preferred to wage their battles in the courts, and usually avoided direct action against Jim Crow practices as a tactic. ${ }^{31}$ Similarly, Juan Williams noted that Thurgood Marshall initially opposed the students' use of the sit-in technique; however, because of support from the African American 
community nationwide, the NAACP Legal Defense Fund eventually took up the cause and defended the students. ${ }^{32}$

\section{THE PARTICIPATION OF BENNETT COLLEGE STUDENTS}

While much has been written about the student sit-ins, primarily concentrating on the four young men from NCA\&T who participated in the February 1 st sit-in, little attention has been given to other participants in the Greensboro protests. African American high school students, church members, and the community at large were all participants in the early demonstrations. ${ }^{33}$ Linda Beatrice Brown in Long Walk: The Story of the Presidency of Willa B. Player at Bennett College reported that during the sitin movement, as much as 40 percent of Bennett College's student body was in the local jail, and they accounted for more than half the students being held at that time in the city. ${ }^{34}$ William Chafe in Civilities and Civil Rights: Greensboro, North Carolina, and the Black Struggle for Freedom declared that the women of Bennett College served as the "foot soldiers" for the sit-in movement by "providing pickets, marchers, and canvassers." 35 Brown found that not only were Bennett and NCA\&T students involved, but many from Greensboro's other colleges, and from at least one local high school, Dudley High School, also participated. ${ }^{36}$

Brown's book documented the presidency of Willa B. Player at Bennett College during the tumultuous years of the Civil Rights Movement and presented new information on these nonviolent protests. ${ }^{37}$ Willa Player received her doctorate from Teachers College, Columbia University in 1948, and was the first African American woman to head a four-year college in the United States, serving as Bennett's president from 1955 through 1966. Earlier researchers made no mention of the percentage of the Bennett student body that was imprisoned, the proportion of Bennett's students among those arrested, or their level of participation and planning of activities in which students were involved. Brown's account corroborates Aldon Morris and Taylor Branch's assertions that these civil rights protests were planned and well-organized efforts to achieve social justice. Linda Brown pointed out that Bennett students regularly participated in "organizational meetings" to plan, strategize, and inspire each other. ${ }^{38}$ Player, when unable to attend these meetings herself, was briefed on the plans by student leader Gloria Brown; and Player supported the strategy sessions by making space available on the Bennett College campus for the meetings. ${ }^{39}$

The earliest example to student activism and protest by Bennett students, as noted by William Chafe, was the picketing of local movie theatres in the 1930 s. $^{40}$ Brown reported that Bennett students launched protests against Greensboro theater owners who censored movies that depicted whites and African Americans as equals. ${ }^{41}$ Along with the Greensboro Citizens Association in 1951 (GCA) and "Operation Door Knock" sponsored by Bennett College in 1960, the students worked to register Greensboro residents 
to vote. ${ }^{42}$ In November 1959 several Bennett students made plans for another protest. This time the effort was to stage a sit-in; however, Player rejected the idea because of the disruption that would occur at the end of the semester when many students were leaving for the holiday break. ${ }^{43}$ However, once the student sit-in protests began in 1960, and during the three years of intensive activity in Greensboro, Player's overwhelmingly positive response was unique among local college presidents. Player and other Bennett College officials openly expressed their support for students' activities. In a February 1960 address at Bennett, Dr. Frederick Patterson, chairman of the college's board of trustees, stated that he regretted that the protests "disturb[ed] the peace and tranquillity of a community ... but once an issue has been joined or faced up to, there should be no turning back until the issue has been successfully resolved," because "segregation on the basis of race ... is morally wrong." Legal segregation was a needless and "cruel affront to the dignity of one race" that encouraged "arrogance and bigotry" in the other. He believed that both races suffered in this situation, and that Greensboro's problem was the result of southern custom and tradition becoming "confused with contacts of a personal and social nature." 44 And in May 1960 while speaking before a group in Boston, Patterson showed support for the students' efforts when he observed that the "demonstrations should be viewed against the background of non-compliance with the law by the South and the total pattern of discrimination." 45 Students, in his opinion, were protesting in an effort to "break the logjam of inequalities." 46 Clearly, the trustees and administration at Bennett were in support of the bold tactics employed by the students as they, through their actions, sought to secure their basic civil rights. By June 1960, Reverend Dr. Martin Luther King, Jr. connected the student sit-ins to the national civil rights campaigns. He declared that these demonstrations were "not merely protests against the refusal of service in eating establishments... [these were] protests against such things as limited job opportunities for Negro college graduates. 47

During the first week the local newspapers chronicled the developing sitin protests. They reported that on 2 February 1960, an additional twentynine students gathered at Woolworth's and occupied seats; on Wednesday, 3 February, participation by students increased even more, and the protesters were able to occupy "sixty-three of the sixty-six seats at the lunch counter." The Greensboro Daily News included its first mention of the involvement of students from Bennett and other colleges in the protests on 4 February 1960.48 Within the first week, a Student Executive Committee for Justice (SECJ) was formed, co-chaired by Bennett College student Gloria Brown, and Ernest Pitt of NCA\&T. This committee's charge was to set strategy, to keep the students informed about the demonstrations, and to recruit new protesters. ${ }^{49}$ As the sit-ins expanded, the committee also coordinated carpools and provided replacement protesters. ${ }^{50}$ By Thursday, 4 February 1960 , three white women from Women's College, and several high school students also joined the black college students from Bennett and NCA\&T. 
Students shifted their attention to the lunch counter at the S. H. Kress Store, down the street from Woolworth's, after the number of participants increased and nearly all seats at the Woolworth's counter were occupied. ${ }^{51}$ Reportedly, the Woolworth and Kress stores were targeted because the students wanted to call attention to national companies whose southern outlets practiced Jim Crow. They also wanted to concentrate their efforts on a few stores so that protesters were not spread too thin. ${ }^{52}$ While only 10 percent of Woolworth's stores were located in the South, stores in other parts of the country did not provide segregated service at lunch counters. However, by the end of the second week of the southern sit-ins, sympathy pickets and protests were launched. Northern picketers were protesting in support of the students' civil rights activities in the South. ${ }^{53}$ Greensboro protesters drew crowds of white teenagers and young men who heckled, and used "abusive and threatening language" in an effort to intimidate and frighten protesters. ${ }^{54}$

Gordon Blackwell, Chancellor of Women's College in Greensboro, began the effort to contain the sit-ins. First, he convinced the three Women's College students to discontinue their participation in the sit-ins; then he called together leaders of Greensboro's other colleges who in turn reached out to the sit-in leaders and proposed a "two-week cooling off period." Students gathered, discussed, and then rejected the proposal; Blackwell subsequently removed himself from the negotiations, indicating that he "felt the time had come for the use of official channels in settling the dispute." ${ }^{55}$ However, on Saturday evening, 6 February 1960, the students voted to suspend demonstrations to provide time for "negotiation and study." 56 That day, "Black Saturday," witnessed the largest protests and a bomb scare, along with announcements from both Kress and Woolworth's that lunch counters would be closed. This resulted in the students' decision to suspend protests. The official statement indicated the protesters would "pin their hopes of being served alongside whites on the use of peaceful channels of negotiation." 57

The official channel for negotiation became the Mayor's Advisory Committee. Mayor George Roach appointed nine citizens to the Advisory Committee on Community Relations; membership included one African American and eight whites. ${ }^{58}$ On 31 March 1960, students were informed of the failure of the Mayor's Advisory Committee to reach a resolution to the lunch counter issue, and students resumed protests. The Committee's recommendation was that establishments designate "an appropriate portion of their seating capacity" for food service to both races and reserve the rest for service to "exclusively white customers." ${ }^{59}$ Reportedly, Woolworth's and S. H. Kress were "extremely sensitive to public reaction" and feared the financial repercussions of desegregated lunch counter service, even if it was on a limited basis. When protest activity resumed in April, after an 8-week negotiation period, forty-five students were arrested for refusing to leave the Kress lunch counter. ${ }^{60}$

Woolworth's regional head C.M. Purdy ordered the counter in the Greensboro store closed on 4 April 1960 and S. H. Kress soon followed suit. 
Woolworth's indicated that "if the people of Greensboro were ready for integration, we'd work with any local committee that would set up the mechanics...." Their focus was on cooperating with local citizens and practices. Paul A. Troast, Chairman of the Board of S. H. Kress, indicated that Kress too would "follow the segregation or integration customs of the communities and cities in which they are located." He felt that Kress should not use their "position as a nationwide company to force a change on any individual city or town"; and suggested that other stores that engaged in the same business also be required to desegregate. ${ }^{61}$ The executives for both stores, it appears, were afraid to take a stand independently in favor of the students' demands, falling back on deference to local custom and practice. On 22 April 1960 large numbers of students were arrested from both Bennett and NCA\&T. The Bennett College students included Mary Ellen Bender, 21, Leonia, NJ; Teresa Anne Brown, 20, Winston-Salem, NC; Lynette Downing, 19, Newport News, VA; Yvonne M. Redcross, 21, Hampton, VA; Nancy Joanne Kirby, 20, Haddonfield, NJ; Margaret Jean Neff, 20, Pottstown, PA; Barbara Ann Stewart, 20, Petersburg, VA; Gloria E. Brown, 23 (no address listed); Gwendolyn Rosetta Mackel, 19, Chicago, IL; and Rosalyn Virginia Cheagle, 20, Lynchburg, VA.62

Protests continued over the next few weeks, and desegregation of the lunch counters in Greensboro was achieved in July 1960, eleven years before Greensboro's public schools were desegregated. The 26 July 1960 headline in the Greensboro Daily News simply read: "Two Stores Integrate Counters; Equal Service Starts Quietly." This was nearly six months after demonstrations began. ${ }^{63}$ Efforts to desegregate other public accommodations would continue through 1963, and Wilma Player continued to support Bennett students' efforts. When several were arrested in 1963, despite pressure placed on her by city leaders to end the demonstrations, Player refused to order Bennett students back to campus, choosing instead to provide them with their course materials and personal necessities while in jail. Her counterpart, Dr. L. C. Dowdy at NCA\&T, ordered his students back to campus. Again, in 1965 nine students from Bennett and NCA\&T were arrested for staging a sit-in at the Mayor's office. Player did nothing to try to change the minds of the students or persuade them to end the protest. Player declared that, "they are a part of this protest and as long as they are willing to stand up for their beliefs until the problem is properly resolved, I'm not looking for an exceptional way to get them out of something that is very difficult, but very important." 64

\section{CONCLUSION}

Linda Brown pointed out that in their formative years the HBCUs incorporated into their teaching models the notion that service to the larger community was an important part of the educational experience. ${ }^{65} \mathrm{We}$ can see this in the leadership and presidency of Willa B. Player at Bennett 
College. This connection to community is one of the reasons Bennett students actively demonstrated against injustices as early as the 1930s and actively sought to empower Greensboro's residents through voter registration drives in the $1950 \mathrm{~s}$ and $1960 \mathrm{~s}$. Therefore, it is no surprise that Bennett students actively participated in the sit-in movement against segregated lunch counter service in Greensboro and other parts of the South. ${ }^{66}$ Bennett students were provided with "encouragement, learning experiences, and moral stamina" they would need to face the challenges of the times in which they lived. ${ }^{67}$ Player evoked the slogan of the American Association of University Women, "Action without study is folly, but study without action is futile," when speaking to the faculty in the fall 1963 to underscore the importance of a link between education and commitment to community. ${ }^{68}$

As noted earlier, Constance Motley contends the Brown decision brought in the "greatest period of social upheaval since the Civil War." With this in mind, it is quite easy to connect the 1960 sit-ins in Greensboro, North Carolina, to the Brown decision. Between 1954 and 1960, several notable events occurred in the emerging Civil Rights Movement, including the Montgomery bus boycott (1955), the outlawing of segregation on public transit by the Supreme Court (1956), the integration of Central High School in Little Rock (1957), and the founding of the Southern Christian Leadership Conference (1957). ${ }^{69}$

The 1954 Brown decision raised the hopes of African Americans who expected to exercise their full rights as citizens in the United States in the near future. The emphasis in Brown II on "all deliberate speed," along with the "massive resistance" employed by southern segregationists, increased resentment and heightened impatience among southern African Americans. Older generations of African Americans had found ways of coping with legal segregation and the negative effects of Jim Crow; however, younger generations of African Americans, including the black women attending Bennett College, were not as tolerant of the slow pace of social change in the United States. They wanted change, and they wanted it to come more quickly than it had in the past. The sit-ins thus can be viewed as the students' way of challenging centuries old customs that sought to keep African Americans in their place, while seeking to make the community, and indeed the country, a better place to live for them and their children.

\section{NOTES}

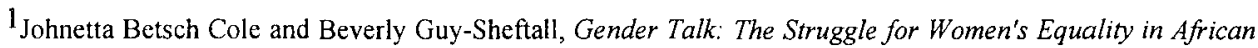
American Communities (New York, NY, 2003).

${ }^{2}$ Serbrenia J. Sims, Diversifying Historically Black Colleges and Universities: A New Paradigm (Westport, CT, 1994), 5-6. An HBCU is an institution that was founded prior to 1964, and is most likely located in the southern Unites States. These institutions date back to the 1850 s, and their primary function was to educate African Americans, many of whom in the late 19th century were formerly enslaved or the descendants of the formerly enslaved African Americans.
}

${ }^{3}$ Taylor Branch, Parting the Waters: America In the King Years 1954-1963 (New York, NY, 1988), 112. 
${ }^{4}$ Constance Baker Motley, Equal Justice under the Law: An Autobiography (New York, NY, 1998), 108.

${ }^{5}$ William H. Chafe, Civilities and Civil Rights: Greensboro, North Carolina, and the Black Struggle for Freedom (New York, NY, 1980), 115. The four NCA\&T students were Ezell Blair, Franklin Eugene McCain, Joseph Alfred McNeil and David L. Richmond.

${ }^{6}$ Greensboro Historical Museum. www.ci.greensboro.nc.us/newsfronts/history/index.htm.

${ }^{7}$ Chafe, Civilities and Civil Rights, 17.

${ }^{8}$ Chafe, Civilities and Civil Right, 5.

${ }^{9}$ Greensboro Historical Museum; Chafe, Civilities and Civil Rights, 6.

${ }^{10}$ Greensboro Historical Museum; Chafe, Civilities and Civil Rights, 5.

${ }^{11}$ Amy Thompson McCandless, The Past in the Present: Women's Higher Education in the Twentieth Century American South. (Tuscaloosa, AL, 1999), 44-45, 181; Chafe, Civilities and Civil Rights, 16. http://library.uncg.edu/depts/archives/history. html. http://www.guilford.edw/about/index. www greensborocollege.edu. The University of North Carolina at Greensboro has gone by several names: 1892-1897, State Normal \& Industrial School; 1897-1919, State Normal and Industrial College; 1919-1932, North Carolina College for Women; 1932-1962, Women's College of the University of North Carolina; after 1963, University of North Carolina at Greensboro.

12 Paula Giddings, When and Where I Enter: The Impact of Black Women on Race and Sex in America (New York, NY, 1984), 261

13"Views Given On Sitdowns By Marshall," Greensboro Daily News, 21 March 1960, A-1; "Over 1,000 Hear Negro Leader," ibid., 4 April 1960, A-1.

14"Students Begin Strategy Talks On Integration," ibid., 16 April 1960, A-1.

${ }^{15}$ Howard Zinn, SNCC: The New Abolitionists. (Westport, CT, 1985), 29; Clayborne Carson, In Struggle: SNCC and the Black Awakening of the 1960s. (Cambridge, MA, 1981), 9.

${ }^{16}$ Aldon D. Morris, The Origins of the Civil Rights Movement: Black Communities Organizing for Change. New York, NY, 1984), 198-199; Taylor Branch, Parting the Waters: America In the King Years 1954-1963, $272-74$.

${ }^{17}$ Chafe, Civilities and Civil Rights, 135-136; Carson, In Struggle, 17-18; Motley, Equal Justice Under the Law, 149.

${ }_{18}$ Robert Weisbrot, Freedom Bound: A History of America's Civil Rights Movement (New York, NY, 1990), 16-39; Zinn. SNCC: The New Abolitionists, 29; Morris, The Origins of the Civil Rights Movement, 198-199; Chafe, Civilities and Civil Rights, 115, 117.

19 "Movement by Negroes Growing," Greensboro Daily News, 4 February 1960, B-1.

20 "Richmond Is Scene of Negro Protests," ibid., 21 February 1960, A-1.

21 "Negroes Fail to Obtain Service," ibid., 3 February 1960, B-1.

${ }^{22}$ Chafe, Civilities and Civil Rights, 99, 137; Linda Beatrice Brown, The Long Walk: The Story of Willa B. Player at Bennett College, (Danville, VA, 1998), 169.

${ }^{23}$ Bettye Collier-Thomas and V. P. Franklin, My Soul is a Witness: A Chronology of the Civil Rights Era 19541965. (New York, NY, 1999), 89, 90, 105.

${ }^{24}$ Hugh Davis Graham, Civil Rights and the Presidency: Race and Gender in American Politics 1960-1972. (New York, NY, 1992), 21.

${ }^{25}$ Chafe, Civilities and Civil Rights, 99; Howard Zinn, SNCC: The New Abolitionists 16, Branch, Parting the Waters, 275; Motley, Equal Justice Under the Law, 131; Juan Williams, Thurgood Marshall: American Revolutionary, (New York, NY, 1998), 287, 289.

${ }^{26}$ Chafe, Civilities and Civil Rights, 120-136.

${ }^{27}$ Benjamin Quarles, The Negro in the Making of America (New York, NY, 1987), 294-295.

${ }^{28}$ Graham, Civil Rights and the Presidency, 22.

${ }^{29}$ Ibid., 22-23.

$30_{\text {Ibid., } 23 .}$.

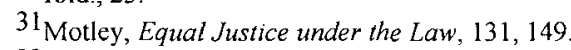

32 Williams, Thurgood Marshall, 287-89.

${ }^{33}$ Morris, The Origins of the Civil Rights Movement, 196.

${ }^{34}$ Brown, Long Walk, 173 
${ }^{35}$ Chafe, Civilities and Civil Rights, 180.

${ }^{36}$ Brown, Long Walk, 168-169.

37 Ibid.

38 Ibid., 172.

${ }^{39}$ Ibid., 172. Gloria Brown is the Bennett College co-chair of the Student Executive Committee for Justice (SECJ). SECJ was formed after the 1 February 1960 initial sit-in to organize the Greensboro sit-in participants. The NCA\&T co-chair was Ernest Pitt.

${ }^{40}$ Chafe, Civilities and Civil Rights, 26-27.

${ }^{41}$ Brown, Long Walk, 161.

42 Ibid., 110-111, 161: Chafe, Civilities and Civil Rights, 35.

43 www.sitins.com/students_faculty.htm

44 "Sitdowns Are Held Inevitable: Ex-College Head Talks at Bennett," Greensboro Daily News, 15 February 1960, B-1.

45 Brown, Long Walk, 169.

$46_{\text {Ibid. }}$

${ }^{47}$ Ibid., 171 .

${ }^{48}$ Chafe, Civilities and Civil Rights, 117 ; "Negroes Fail To Obtain Service" Greensboro Daily News, 3 February 1960, B-1; "Movement By Negroes Growing: No Service Given Students," Greensboro Daily News, 4 February $1960, \mathrm{~B}-1$.

${ }^{49}$ Chafe, Civilities and Civil Rights, 117-118; Brown, Long Walk, 171.

${ }^{50}$ Chafe, Civilities and Civil Rights, 117-118.

51 "Aid Given Negroes' Protest: 3 WC Students Join Sit-down," Greensboro Daily News, 5 February 1960, B-1; Chafe, Civilities and Civil Rights, 118-119.

52"Mass Negro Protests Hit Durham, Winston," Greensboro Daily News, 9 February 1960, A-1; "N.C. Stores Close Down Counters," ibid., 10 February 1960, A-1; "Nationwide Boycott Of Stores Sought," ibid., 17 February 1960, A.4.

${ }^{53}$ Chafe, Civilities and Civil Rights, 120, "Counters to Remain Closed: Decision Made By 2 Stores," Greensboro Daily News, 8 February 1960, B-1; "Mass Negro Protests Hit Durham, Winston," ibid., 9 February 1960, A-1; "N.C. Stores Close Down Counters," ibid., 10 February 1960, A-1.

${ }^{54}$ Chafe, Civilities and Civil Rights, 118 ; "Aid Given Negroes' Protest: 3 WC Students Join Sit-down," Greensboro Daily News, 5 February 1960, B-1

${ }^{55}$ Chafe, Civilities and Civil Rights, 122-123; "A\&T Students Call Two-Week Recess in Protest Here," Greensboro Daily News, 7 February 1960, A-1; "Picketing of Stores is Planned: Demonstrations Slated In New York," ibid., 10 February 1960, B-1. By official, Blackwell was referring to actions to be determined and implemented by the elected officials of Greensboro.

${ }^{56}$ Chafe, Civilities and Civil Rights, 118-119; "A\&T Students Call Two-Week Recess in Protest Here," Greensboro Daily News, 7 February 1960, A-1.

57"A\&T Students Drop Sit-down Protests; Plan Negotiations," Greensboro Daily News, 21 February 1960, A1. Black Saturday was 6 February 1960.

58 "Gains Seen in Settling Race Issue: Commission Is Organized," Greensboro Daily News, 27 February 1960, B-1. Appointees to the Mayor's Advisory Committee included: Councilman E. R. Zane, committee chair; Councilman Waldo Falkener; Bland Worley; Councilman David Schenck, Arnold Schiffman, O. L. Fryman, Howard Holderness, James A. Doggett, and W. M. York.

59 "Text of Report By Advisory Committee to Mayor George Roach of Greensboro," Greensbaro Daily News, 2 April 1960, A-3.

60 "Protests Are Resumed At Lunch Counters: Two Stores Blamed," Greensboro Daily News, 2 February 1960, A-1.

61 "Woolworth to Close Counter: Food Sale Ends for Time Being," Greensboro Daily News, 5 April 1960, A-1; "Kress Store Again Opens Counter," 6 April 1960, B-1; "Kress Co. To Follow Custom, ibid., 18 May 1960, A5.

${ }^{62}$ Chafe, Civilities and Civil Rights, 131.

63 "Two Stores Integrate Counters: Equal Service Starts Quietly," Greensboro Daily News, 26 July 1960, B-1. 
${ }^{64}$ Brown, Long Walk, 173.

$65_{\text {Ibid. }} 55$.

$66_{\text {Ibid., } 93 .}$

${ }^{67}$ Ibid, 174

$68_{\text {Ibid., } 158 .}$

${ }^{69}$ Collier-Thomas and Franklin, My Soul is a Witness, 6, 18, 42, 56, 57. 